\title{
How Much Is the Financial Structure of Italian Textile SMEs?
}

\author{
Loris Nadotti, Valeria Vannoni \\ University of Perugia, Perugia, Italy
}

\begin{abstract}
The textile sector in Italy has traditionally played an important role in the national economy: To date, it weighs about $4 \%$ of GDP. Despite international competition, the sector maintains its importance which is internationally recognized. The firms in the sector are committed to remaining competitive, investing in innovation and communication, increasingly seeking internationalization. To keep up with the competition, it is necessary to have financial resources to cover these investments. In Italy, with the exception of some great outliers, the sector is dominated by small and medium-sized enterprises: The small size makes often more difficult to raise funds. The paper aims to analyze the cost of financing for small and medium enterprises (SMEs) in the Italian textile sector, verifying also if it remains a prevailing orientation towards debt financing. Using the Weighted Average Cost of Capital (WACC) formula, the study focuses on 2,446 companies, with financial data available on the Orbis database by Bureau van Dijk. Results confirm a strong unbalanced structure towards debt financing; however, the cost of capital is mitigated by the cost of “standing alone” debt, much lower than that one of shareholders' funds.
\end{abstract}

Keywords: capital structure, cost of capital, small business financing, textile sector

\section{Introduction}

Choices about the composition of the financial structure of firms are strongly affected by the size and the sector of companies: Small enterprises in sectors with low capital intensity are most frequently involved in debt financing. Firms may find themselves in difficulty in raising financial resources, with problems that in many cases are amplified by the small size of the company. The weight of debt and equity on the financial structure of firms affects the cost of capital, so it is appropriate to seek that composition of funds that is able to reduce the financial burden for the company. In this study we want to investigate these aspects with reference to the case of firms in the Italian textile sector. The choice is justified by the importance of the sector in the economy of the country and by the typical minor dimensions of the companies. The paper analyzes the cost of the financial structure of the companies, starting from the weights that shareholders' funds and debt have on it. The purpose is to verify whether there is an imbalance in the financial structure towards the debt, therefore an under-capitalization of the companies and to estimate the cost of the financial structure, evaluating even if there are differences based on the geographical area of the firms.

The paper is organized in the following paragraphs: (1) introduction; (2) literature review; (3) empirical verification (a. methodology; b. results); (4) conclusions.

Loris Nadotti, full professor in Financial Markets and Institutions, Department of Economics, University of Perugia, Italy. Valeria Vannoni, Ph.D. in banking and finance, lecturer at Department of Economics, University of Perugia, Italy. Correspondence concerning this article should be addressed to Valeria Vannoni, Via Pascoli, 20, Perugia 06123, Italy. 


\section{Literature Review}

After the first theorization about capital structure and firm value by Modigliani and Miller (1958), some main theories have been developed, analyzing the topic through a hierarchy (pecking order theory; Myers, 1984; Myers \& Majluf, 1984) or a trade-off (trade-off theory; Jensen \& Meckling, 1976; Myers, 1977; Jensen, 1986) between the alternatives of financing, or introducing the relevance of the timing as a determining factor for the choice (market timing theory; Baker \& Wurgler, 2002).

Financial literature has highlighted over the time the convenience of debt financing due to benefits from the tax shield; however, yet starting from Robicheck and Myers (1965), empirical studies have also deepened the criticalities connected to an excessive use of this form of financing (bankruptcy cost theory). Many studies on the capital structure have shown that the main different theories about the topic are not necessarily exclusive of one another. Despite of non-univocal results, the common conviction of the need to adequately quantify the cost of capital was affirmed. In this regard, the weighted average cost of capital has affirmed itself as a synthetic and effective measure of the cost of the financial structure of firms.

With specific regard to Italy, an effective synthesis of the main contributions on the financial structure of Italian firms is proposed in Scannella (2016). Generally, literature has mainly focused on the analysis of debt financing, given the prevalent orientation of small and medium-sized enterprises towards bank debt. Outside this box, Baldi and Zazzara (2006) deepen the role of equity in firm financing, while Trovato and Alfò (2006) analyze the effect of public subsidies on the development path of Italian small and medium enterprises (SMEs).

Referring to traditional theories about capital structure, Brighi and Torluccio (2007) find that, although the financial hierarchy theory suggests that firms prefer self-financing, because it is less expensive in economic terms, relationships with local banks may offer advantages which encourage firms to enter into debt contracts even in the absence of binding internal constraints. Their results, in line with the pecking order theory, confirm an approach comprising an initial check on the availability of internal resources, followed if by the use of external capital, including bank debt. Intrisano (2012) states that it is not possible to say with certainty which financial structure theory better represents the behavior of Italian firms concerning financial structure. Bigelli, Martín-Ugedo, and Sánchez Vidal (2014) analyze the factors that motivate private firms to follow a conservative financial policy. Using a new definition of financial conservatism, they look for the determinants of financial conservatism according to the main theories of capital structure and financing policy. Their findings show that financially conservative firms are smaller, with more intangible and less tangible assets, lower effective tax rates and follow a pecking order style financial policy. Other authors, on the other hand, proposed different interpretations of the composition choices of the financial structure of firms, considering some elements characteristic of the Italian economic environment, such as regionalism, firm-bank relationship, restricted ownership, debt maturity, and fiscal variables. Di Pietro, Bontempi, Palacin-Sánchez, and Samaniego-Medina (2016) analyze how the regional financial and economic differences influence the capital structure decisions of small and medium-sized enterprises. Specifically, they consider the regional financial and economic differences dividing four main aspects: the development of the financial sector in the region; the bank market concentration; the financial cost of obtaining funds; the regional economic development. Their results show that differences in the degree of financial sector development, banking concentration, costs of funding, and local economic situation have a significant impact on the level of leverage of SMEs, while the cost of obtaining funds is only relevant in a period of economic stability. These results suggest that more insights can 
derive from the data disaggregation at the regional level inside the same country, rather than from cross-country data in the analysis of capital structure. Elston and Rondi (2006) indicate that concentrated inside ownership increases the cost of capital for Italian firms and the magnitude of capital stock distortions is found to be quite important in Italy. Bontempi, Giannini, and Golinelli (2005) measure the relationship between fiscal variables and corporate debt choices. They find that both the trade-off relative price of debt and equity finance, and the pecking-order net-of-tax cash flow, are significant, robust ways by which corporate taxation affects financing decisions. Molinari, Fagiolo, and Giannangeli (2008) study the relationships between firm financial structure and growth, testing whether liquidity constraints affect firm performance by considering among growth determinants also firm debt structure. Their analyses show that, among others, firms do not use their capital to expand, but rather to increase debt. Mantovani (2014), investigating whether the debt quality matters and the role of debt maturity choice (as yet previously in Lamieri, 2009), underlines that longer maturities tends to increase the cost of debt, with significant relations between debt maturity and company size and a specific contribute of debt maturity to value of the tax shield. De Socio (2010), in a comparative study among European countries, confirms that a high indebtedness, with respect both to turnover and to risk capital, gives rise to a bigger impact of interest payments. Moreover, the weight of short-term debt for Italian firms is higher and the availability of liquid assets is lower. Finally the percentage of commercial debt on assets is quite high. Taking all into account, the financial fragility is confirmed by the higher share of Italian firms which are vulnerable compared to European average. Molinari, Giannangeli, and Fagiolo (2016) suggest that fast-growing firms are characterized by higher growth/cash-flow sensitivities and heavily rely on external debt, but seem to be less bank-backed than other firms. Summarizing all the contributions analyzed, it can be concluded that the choices regarding the capital structure of Italian firms are heavily affected by the intensity of firm-bank relationship, the limited use of the financial market, the peculiarities of different geographical areas.

\section{Empirical Analysis}

\section{Methodology}

The verification involves companies with financial data available in Orbis database by Bureau van Dijk, according to the following research strategy:

\begin{tabular}{|l|l|}
\hline Item & Specification \\
\hline Country & Italy \\
\hline Primary code (NAICS 2017) & Apparel manufacturing \\
\hline Type of accounts & Unlisted companies with unconsolidated accounts only \\
\hline Total assets, maximum value & 43,000 th. eur \\
\hline Operating turnover, maximum value & 50,000 th. eur \\
\hline Number of employee, maximum value & 50 \\
\hline
\end{tabular}

Figure 1. Criteria for sample definition. Source: author's elaboration.

Firms meeting the research requirements are 2,446. Thus, we distinguished companies by geographical area: North West (524), North East (609), Centre (682), South (600), Insular Italy (31).

To determine the cost of capital of companies, following the portfolio theory fundamentals (Markowitz, 1952), we use the formula of Weighted Average Cost of Capital (WACC):

$$
\mathrm{WACC}=\mathrm{W}_{\mathrm{e}} \mathrm{K}_{\mathrm{e}}+\mathrm{W}_{\mathrm{d}} \mathrm{K}_{\mathrm{d}}(1-\mathrm{t}) \text {, }
$$

where $\mathrm{W}_{\mathrm{e}}$ = percentage of financing from equity; $\mathrm{W}_{\mathrm{d}}$ = percentage of financing from debt; $\mathrm{K}_{\mathrm{e}}=$ cost of equity; 
$\mathrm{K}_{\mathrm{d}}=$ cost of debt; $\mathrm{t}=$ corporate tax rate.

Due to the large number of firms in the sample and difficulties in applying the fair value approach, we approximated $\mathrm{W}_{\mathrm{e}}$ and $\mathrm{W}_{\mathrm{d}}$ values calculating themselves through accounting data for shareholders' fund, debt and total liabilities.

To estimate the cost of equity, we use the Capital Asset Pricing Model (CAPM) formula (Sharpe, 1964):

$$
K_{e}=R_{f}+\beta\left(R_{m}-R_{f}\right) \text {, }
$$

where $R_{f}=$ risk free rate; $\beta$ = systematic risk coefficient; $R_{m}=$ market return coefficient.

To estimate the cost of debt, we use the theoretical model of synthetic rating (Damodaran, 2001):

$$
\mathrm{K}_{\mathrm{d}}=\mathrm{R}_{\mathrm{f}}+\text { credit spread. }
$$

As risk free rate $\left(\mathrm{R}_{\mathrm{f}}\right)$, we consider the average return in one year on 10-year BTP (multi-year Italian Government bonds), that is equal to $2.379 \%$. For beta coefficient, we use a bottom up methodology, starting from the average beta of economic sector (BRI, business risk index) and, then, through the relevering technique, we determine the levered beta. Industry unlevered beta data are from A. Damodaran; BRI indexes refer to the European context. The term $\left(\mathrm{R}_{\mathrm{m}}-\mathrm{R}_{\mathrm{f}}\right)$ is the market risk premium; according to Fernandez (2017), we treat it as a random variable, estimated therefore by statistical inference and equal to $6.1 \%$. The corporate tax rate is identified as in the Italian income tax law (L. n. 208/2015).

To attribute the credit spread in the estimate of the cost of debt, we calculated the EBIT/OF ratio (Earnings Before Interest and Taxes/Financial Expenses) for all the companies and then assigned the corresponding values using sources by A. Damodaran.

\section{Results}

We obtained the results in Table 1 for the described variables.

Table 1

Estimated Values for Main Variables

\begin{tabular}{lllll}
\hline & $\mathrm{W}_{\mathrm{e}}$ & $\mathrm{W}_{\mathrm{d}}$ & $\mathrm{K}_{\mathrm{e}}$ & $\mathrm{K}_{\mathrm{d}}$ \\
\hline North West & 29.58 & 70.42 & 27.58 & 8.76 \\
North East & 26.10 & 73.90 & 29.11 & 7.76 \\
Centre & 21.90 & 78.10 & 30.32 & 5.89 \\
South & 20.79 & 79.21 & 29.31 & 10.74 \\
Insular Italy & 19.08 & 80.92 & 31.11 & 10.13 \\
\hline
\end{tabular}

Source: author's elaboration.

Firms have a strong unbalanced financial structure: In all geographical areas debt is considerably higher than the equity. This result is in line with the traditional orientation of the Italian entrepreneurial system towards bank financing (Ordanini \& Zanetti, 1997; Lusignani \& Sironi, 1999; Della Bella, 2000; De Cecco, 2003; Venanzi, 2005; Palazzi, 2012; Mazzoleni, 2016).

WACC results are as in Table 2.

In none of the geographical areas the composition of funding reduces the cost of capital compared to the exclusive debt financing; equity is so much more expensive in all areas of the country. The regions of central Italy have the lowest level of the cost of capital, while the regions in North West are the highest. This is quite a surprise compared to the expectation that a lower cost would be in the economically stronger geographical areas, due to the bargaining power of firms. 
Table 2

Estimated Values for WACC

\begin{tabular}{ll}
\hline & WACC \\
\hline North West & 12.29 \\
North East & 11.44 \\
Centre & 9.72 \\
South & 11.79 \\
Insular Italy & 11.34 \\
\hline
\end{tabular}

Source: author's elaboration.

\section{Conclusions}

In this paper, we focused on the financial structure of Italian textile firms, particularly on apparel manufacturing firms. The originality of the contribution can be traced back to the focus on a sector to which no other specific work is dedicated. The choice of Italy is justified by two main reasons: the relevance of leverage in firms (Intrisano, 2012); the importance of the textile sector in the country's economy. Results are in line with main studies on the financial structure of Italian small and medium-sized enterprises, and reveal an overwhelming prevalence of debt financing. Composition of funding is not able to reduce the cost of capital; differences in the cost of capital do not reflect the different levels of economic development among regions. Further research could include a deepening on debt maturity.

\section{References}

Baker, M., \& Wurgler, J. (2002). Market timing and capital structure. The Journal of Finance, 57(1), 1-32.

Baldi, F., \& Zazzara, C. (2006). Who uses equity capital among SMEs? Evidence from survey data. Retrieved from ssrn.com

Bigelli, M., Martín-Ugedo, J. F., \& Sánchez Vidal, J. (2014). Financial conservatism of private firms. Journal of Business Research, 67(11), 2419-2427.

Bontempi, M. E., Giannini, S., \& Golinelli, R. (2005). The trade-off and pecking-order empirical effects of corporate taxation on financial choices: A unified approach. Retrieved from ssrn.com

Brighi, P., \& Torluccio, G. (2007). Evidence on funding decisions by Italian SMEs: A self-selection model? Retrieved from ssrn.com

Damodaran, A. (2001). Corporate finance: Theory and practice (International Edition). New York, NY: Willey.

De Cecco, M. (2003). Piccole imprese, banche, commercialisti. Note sui protagonisti della seconda industrializzazione italiana. Atti di intelligenza e sviluppo economico. Saggi per il bicentenario della nascita di Carlo Cattaneo (Eds.). Luciano Cafagna and Nicola Crepax, Bologna, pp. 425-449.

De Socio, A. (2010). The economic and financial situation of Italian non financial corporations: An international comparison. Bank of Italy Occasional Paper No. 66. Retrieved from ssrn.com

Della Bella, C. (2000). Letture per il corso di Finanziamenti di Aziende. Milan: Università L. Bocconi.

Di Pietro, F., Bontempi, M. E., Palacin-Sánchez, M. J., \& Samaniego-Medina, R. (2016). Capital structure across Italian regions: The roles of financial and economic determinants. Retrieved from ssrn.com

Elston, J. A., \& Rondi, L. (2006). Shareholder protection and the cost of capital: Empirical evidence from German and Italian Firms. Ceris-CNR Working Paper No. 8-2006. Retrieved from ssrn.com

Intrisano, C. (2012). The financial structure of Italian companies. Chinese Business Review, 11(8), 748-759.

Jensen, M. C. (1986). Agency costs of free cash flow, corporate finance, and takeovers. The American Economic Review, 76(2), 323-329.

Jensen, M. C., \& Meckling, W. H. (1976). Theory of the firm: Managerial behavior, agency costs and ownership structure. Journal of Financial Economics, 3, 305-360.

Lamieri, M. (2009). Debt maturity structure of Italian firms. Retrieved from ssrn.com

Lusignani, G., \& Sironi, A. (1999). Il rapporto fra banche e PMI: Pricing, rischio e modelli comportamentali. In G. Forestieri and M. Onado (Eds.), L’innovazione nel finanziamento delle piccole e medie imprese. Milan: Newfin, Egea. 
Mantovani, G. M. (2014). The maturity drivers of corporate capital structure of private/unlisted companies. Retrieved from ssrn.com

Mazzoleni, A. (2016). Il finanziamento all'impresa. La scelta tra debito e capital. Milan: Franco Angeli.

Myers, S. C. (1977). Determinants of corporate borrowing. Journal of Financial Economics, 5, 147-175.

Myers, S. C. (1984). The capital structure puzzle. The Journal of Finance, 39(3), 574-592.

Myers, S. C., \& Majluf, N. S. (1984). Corporate financing and investment decisions when firms have information that investors do not have. Journal of Financial Economics, 13(2), 187-221.

Modigliani, F., \& Miller, M. H. (1958). The cost of capital, corporation finance and the theory of investment. The American Economic Review, 48(3), 261-297.

Molinari, M., Giannangeli, S., \& Fagiolo, G. (2016). Financial structure and corporate growth: Evidence from Italian panel data. Economic Notes, 45(3), 303-325.

Molinari, M., Fagiolo, G., \& Giannangeli, S. (2008). Financial structure and corporate growth, evidence from Italian panel data. Retrieved from ssrn.com

Ordanini, A., \& Zanetti, L. (1997). Le dinamiche di crescita delle PMI italiane: Modalità relazioni e vincoli finanziari. Finanza, Marketing e Produzione, No. 4. . Milan: Bocconi University.

Palazzi, F. (2012). Medie imprese italiane, sviluppo e corporate Finance. Milan: Franco Angeli.

Robicheck, A. A., \& Myers S. C. (1965). Optimal financing decisions. Englewood Cliffs. New Jersey: Prentice Hall.

Scannella, E. (2016). Profili teorici ed Evidenze empiriche del rapporto Banca-Impresa. Un'Indagine sul Territorio. Milan: Franco Angeli.

Sharpe, W. F. (1964). Capital asset prices: A theory of market equilibrium under conditions of risk. The Journal of Finance, 19 (3), 425-442.

Trovato, G., \& Alfò, M. (2006). Credit rationing and the financial structure of Italian small and medium enterprises. Journal of Applied Economics, 9(1), 167-184.

Venanzi, D. (2005). Specificità finanziarie delle medie imprese italiane: Un'analisi del campione Mediobanca-Unioncamere. Argomenti, No. 3. Milan: Franco Angeli. 